DOS PASSOS AND THE FICTION OF DESPAIR 


\section{DOS PASSOS AND THE FICTION OF DESPAIR}

IAIN COLLEY

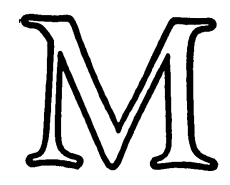


(C) Iain Colley 1978

Softcover reprint of the hardcover 1st edition 1978

All rights reserved. No part of this publication may be reproduced or transmitted, in any form or by any means, without permission

First published 1978 by THE MACMILLAN PRESS LTD London and Basingstoke Associated companies in Delhi Dublin Hong Kong Johannesburg Lagos Melbourne New York Singapore Tokyo

Typeset in Great Britain by The Bowering Press Ltd Plymouth

\section{British Library Cataloguing in Publication Data}

Colley, Iain

Dos Passos and the fiction of despair

1. Dos Passos, John - Criticism and interpretation I. Title.

813'.5'2 PS3507.0743Z/

This book is sold subject to the standard conditions of the Net Book Agreement 
For Liz, Scott and Marius and for my Mother 


\section{Contents}

Acknowledgements viii

$\begin{array}{ll}\text { Introduction } & 1\end{array}$

1 The Ether Cone: Harvard and Streets of Night 13

2 'Getting in Bad': One Man's Initiation 1917 and $\begin{array}{lr}\text { Three Soldiers } & 27\end{array}$

3 Brownian Motion: Manhattan Transfer 47

4 America Can Break Your Heart: USA 66

5 'Rejoining the United States': District of Columbia and the Later Fiction

$\begin{array}{lr}\text { Notes } & 147\end{array}$

$\begin{array}{ll}\text { Selected Bibliography } & 161\end{array}$

$\begin{array}{lr}\text { Index } & 169\end{array}$ 


\section{Acknowledgements}

No one but myself is to blame for any errors of fact or oddities of judgement in the following pages. However, I should like to record multifarious debts of gratitude to the following: Nigel Builder; Keith Carabine: James Epstein; Anita Newton; Shaie Selzer; John Whitley.

Special thanks are due to my wife, who not only gave her energy and patience to the typing of my script but bravely tolerated unpleasant moods into which the researching and writing of this book cast me.

I should also like to record my thanks to Mrs Elizabeth Dos Passos, who has been generous in granting permission to quote from her late husband's works.

I.M.C.

June 1977 